\title{
PROMOTING DIALOGUE \\ AND ACTION ON \\ META-PROFESSIONAL \\ SKILLS, ROLES, AND \\ RESPONSIBILITIES
}

\author{
Michael Theall, Youngstown State University \\ Bonnie Mullinix, Teaching Learning and \\ Technology Group \\ Raoul A. Arreola, University of Tennessee \\ Health Science Center
}

Collecting and using information about faculty skills can serve as an organizational development activity to guide faculty evaluation and professional development policy and practice with the goal of leading to improved teaching and learning. This chapter presents findings from a study with international, local, quantitative, and qualitative components. Readers are encouraged to explore data patterns and consider courses of action that these imply, and to reflect on the potential usefulness of the Meta-Profession model for furthering reflection, dialogue, and action on development and evaluation processes on their own campus.

What is it that faculty do, and how should they be supported to excel at their core work? This central question permeates the academy and serves as the foundation for the work of those who support faculty to excel and succeed. The Meta-Profession Project was designed to address this question and has been doing so for nearly a decade. Results and experience over this period indicate that the model and findings from quantitative international survey research and qualitative context-grounded explorations can inform and promote dialogue, discussion, and action that will enhance the understanding and the experience of the professoriate. 


\section{History and Background of the Study}

The past twenty years have seen many efforts to define the nature of the professoriate. Ernest Boyer's redefinition of scholarship (1990), the AAHE Forum on Faculty Roles and Rewards led by Gene Rice, and Diamond and Adam's books $(1995,2000)$ about disciplinary perspectives on faculty work have supplied a conceptual basis and real-world data for our thinking about what it means to be a college professor. However, to completely understand the work that the profession demands, we must also explore the skills that the work requires (Arreola, Theall, \& Aleamoni, 2003; Theall, 2002; Theall \& Arreola, 2006). Until we identify the generic and specific skills necessary to succeed in the four basic professorial roles (teaching, scholarly and creative activities, service, and administration), we cannot hope to evaluate that work effectively or offer meaningful support for those who do it. Equally important in times when the status of the professoriate has been diminished, it is critical to demonstrate that being a college professor involves much more than presenting one's expertise in a classroom for a few hours a week. We view college teaching as a "meta-profession," that is, a profession that requires expertise in a variety of complex professional skills beyond that of content expertise.

Our work in this area is called the Meta-Profession Project. The survey and integrated study (quantitative and qualitative) and action-oriented process presented herein are part of an ongoing effort to describe, define, explore, and support the professoriate. The Meta-Profession Project is described in detail at www.cedanet.com/meta (and in various papers and articles available at that Web location). By way of an introductory summary, the Meta-Profession Project has four main objectives:

Engage college faculty in providing more precise information about the frequency with which the various identified skills are required in their work.

Gather information that will permit the determination as to whether faculty expertise in, and patterns of use of, the skill sets vary from institution to institution and as a function of other variables.

Present a structure (the meta-professional matrices) that can be used effectively in faculty development and evaluation, policy decision making, research, and important campus dialogue. Gather information on, and constitute, a central source for resource materials about the various skill sets in support of improved faculty evaluation, faculty development, research, 
and campus policies and practices affecting the professoriate. Ultimately, the goals of the Meta-Profession Project are to contribute to systematic improvement of teaching and learning, enhance the effectiveness of higher education institutions, and promote recognition of the professoriate as a truly complex and higher calling.

A first step in the project was development of a framework that defined the Meta-Profession concept. Table 7.1 summarizes twenty skill sets required of faculty. These meta-professional skills include designing, constructing, and operating a complex environment that facilitates and supports student learning; working with and leading others; mastering the use of complex technologies; and representing one's work and institution to a variety of academic colleagues and to the public.

Frequency estimates for each skill set were originally developed on the basis of evidence in existing literature, on our own work in faculty development and evaluation over the past three decades, and in consultation with colleagues in these and other fields. Discussions of faculty work exist (Braskamp \& Ory, 1994; Gappa, Austin, \& Trice, 2007), but explorations of the actual skills required to do that work were not available. Table 7.2 thus presents estimates of the frequency of need for each skill set in four roles (teaching, scholarly and creative activities, service, and administration). These estimates use the terms "almost always," "frequently," "occasionally," and "almost never" (abbreviated as "always," "freq," "occa," and "never").

One finding that has been constantly identified as immediately apparent in the matrix is that graduate school training focuses extensively on the "base profession" but rarely supports preparation for the many other requirements of the meta-profession. The twenty skill sets identified in Table 7.2 indicate the range of capabilities necessary for faculty to succeed in their four primary roles. Additional matrices that examine subsets or application of skills within each faculty role may be seen at the MetaProfession Project website (for example, the need for various skill sets associated with seven teaching situations, from large classes to online instruction to tutoring). These additional matrices, along with color versions of Tables 7.2 through 7.7 , can be viewed at www.cedanet.com/meta.

\section{An International Study}

In 2007, the Professional and Organizational Development (POD) Network in Higher Education and the Special Interest Group in Faculty Teaching, Evaluation, and Development of the American Educational 


\section{Table 7.1. Meta-Professional Skill Set Definitions}

Skill Set

\section{Brief Definition or Description}

\section{Base Profession Skill Sets}

Content expertise

Practice and clinical skills

Research techniques
The formally recognized knowledge, skills, and abilities a faculty member possesses in a chosen field by virtue of advanced training, education, or experience.

Those skills in translating content expertise into actions so as to carry out a process, produce a product, or offer a service.

Those skills in acquiring existing knowledge, or creating or discovering new knowledge, within one's area of content expertise.

\section{Meta-Profession Skill Sets}

Instructional Those technical skills in designing, sequencing, and present-

design ing experiences that induce learning. Requires knowledge and skill in task analysis, the psychology of learning, the conditions of learning, and development of performance objectives.

Instructional Those human interactive skills that promote or facilitate delivery learning in face-to-face instruction, as well as those skills in using various forms of instructional delivery mechanisms.

Instructional Those skills in developing and using tools and procedures assessment for assessing student learning (including test construction, questionnaire and survey construction, grading practices, and grading procedures).

Course management Those organizational and bureaucratic skills involved in Instructional research

Psychometrics and statistics maintaining and operating a course.

Those technical skills and techniques associated with scholarly inquiry into all aspects of instruction, teaching, and education.

Psychometrics and statistics is concerned with measurement of human characteristics and design and analysis of research based on those measurements.

Epistemology The branch of philosophy that studies the nature and limits of knowledge as well as examining the structure, origin, and criteria of knowledge. Its application can often be seen in course or curriculum design in which the structure of the knowledge to be acquired by the student is taken into account in designing instructional events or experiences.

Learning theory Learning theory deals with various models to explain how learning takes place and to furnish a frame of reference for designing, developing, and delivering instruction. 
Human Theories and models of human intellectual, ethical, social, development cultural, and physical development. Knowledge and expertise in the theories of human development are often required in designing and developing the entire educational experience.

Information Information technology (IT) encompasses all forms of techtechnology nology used to create, store, exchange, and use information in its various forms (business data, voice conversations, still images, motion pictures, multimedia presentations).

Technical writing

Delivery of technical information to readers (or listeners or viewers) in a manner that is adapted to their needs, level of understanding, and background. The primary skill is to write about highly technical subjects in such a way that a beginner (learner) or a nonspecialist can understand.

Graphic design Graphic design is the process and art of combining text and graphics to produce an efficient and effective means of visually communicating information or concepts.

Public speaking Public speaking is generally defined as speaking to a large group of individuals, in a formal setting, for the purpose of imparting information or persuading others to a particular point of view.

Communication Individuals have various preferences for both communicating styles with others and interpreting communications from others. Numerous models have been developed that describe how to recognize people's preferred style of communicating and what strategy to use in communicating most effectively with them.

Conflict The practice of identifying and handling conflict sensibly, management fairly, and efficiently. Conflict management requires such skills as effective communicating, problem solving, and negotiating with a focus on interests.

Group process, Groups of individuals, gathered together to achieve a goal or team building objective, either as a committee or some other grouping, go through several predictable stages before useful work can be done.

Resource Management of material resources so as to ensure their effecmanagement tive and efficient use in meeting specific purposes. Involves skills associated with inventory control procedures, replacement and maintenance scheduling, cost control, etc.

Personnel Skills in communicating effectively, developing teams, manmanagement aging diversity, managing conflict, delegating responsibility, coaching and training, giving and receiving constructive feedback, and motivating and guiding either individuals or groups to achieve specific goals. 


\section{Table 7.1. (Continued)}

\section{Skill Set}

Financial and budget development

Policy analysis and development

\section{Brief Definition or Description}

Requires understanding of a variety of economic and monetary concepts, including cash flow, direct and indirect costs, debt management, depreciation, etc.; the ability to read and understand financial reports; and the ability to interpret and respond appropriately to federal, state, and local regulations and policies affecting expenditure of funds.

Those skills necessary for understanding the political constraints faced by policy makers, assessing the performance of alternative approaches to policy implementation, evaluating the effectiveness of policies, and the role that values conflict has on development of policies.

Note: The term skill set is used to indicate a combination of knowledge, experience, proficiency, and skill in a specific area.

Research Association (AERA-SIGFTED) agreed to cosponsor a research project intended to validate the Meta-Profession conceptual model and to explore several issues surrounding its application in faculty development and evaluation. The survey was international in scope and circulated by professional organizations to their members, by some of those members to faculty and administrators at their individual campuses, and by individuals interested in the research. Requests for participation were disseminated in the United States and several other countries. There were 415 responses from the United States and 114 from other countries, primarily Canada. Additional data were collected at one institution in a separate survey, and seventy-four persons responded.

One of the first questions addressed was the extent to which the original model (see Table 7.2) was accurate in its estimates of the need for the skill sets. The data essentially validated the summary matrix representation of the need for the skill sets, and Theall et al. (2008) reported preliminary analyses. However, an equally important question was the extent to which faculty possessed expertise in the skill sets. Thus, in the same survey faculty were asked to self-report their expertise, and administrators were asked to report their estimates of the skills of the faculty with whom they worked. Because "base-profession" skills (content expertise, clinical and practical skills, and research techniques) are the focus of graduate education and prime criteria for entry into the professoriate, a high level of expertise was expected and the assumption was made that faculty would regularly need these skills. Thus, further analysis concentrated only on the meta-professional skill sets. 
Table 7.2. An Overview of the Meta-Professional Model: Estimated General Frequency of Need for Each Skill Set in Four Traditional Faculty Roles

\begin{tabular}{|c|c|c|c|c|}
\hline & & Faculty & Roles & \\
\hline $\begin{array}{l}\text { FACULTY } \\
\text { SKILL SETS }\end{array}$ & $\begin{array}{c}\text { Teaching } \\
\text { Role }\end{array}$ & $\begin{array}{c}\text { Scholarly } \\
\text { and Creative } \\
\text { Activities } \\
\text { Role }\end{array}$ & $\begin{array}{c}\text { Service } \\
\text { Role }\end{array}$ & $\begin{array}{c}\text { Administrative } \\
\text { Role }\end{array}$ \\
\hline \multicolumn{5}{|l|}{ BASE-PROFESSION SKILLS } \\
\hline Content Expertise & Always & Always & Occa & Never \\
\hline Practical-Clinical Skills & Freq & Freq & Occa & Never \\
\hline Research Techniques & Occa & Freq & Never & Never \\
\hline \multicolumn{5}{|l|}{ META-PROFESSION SKILLS } \\
\hline Instructional Design & Always & Occa & Occa & Never \\
\hline Instructional Delivery & Always & Occa & Occa & Never \\
\hline Instructional Assessment & Always & Occa & Occa & Never \\
\hline Course Management & Freq & Occa & Occa & Never \\
\hline Instructional Research & Never & Freq & Occa & Never \\
\hline Psychometrics/Statistics & Occa & Freq & Occa & Never \\
\hline Epistemology & Occa & Occa & Occa & Never \\
\hline Learning Theory & Freq & Occa & Occa & Never \\
\hline Human Development & Occa & Occa & Occa & Never \\
\hline Information Technology & Freq & Freq & Occa & Occa \\
\hline Technical Writing & Occa & Freq & Occa & Never \\
\hline Graphic Design & Occa & Occa & Occa & Never \\
\hline Public Speaking & Freq & Freq & Occa & Freq \\
\hline Communications Styles & Freq & Freq & Occa & Freq \\
\hline Conflict Management & Occa & Never & Occa & Freq \\
\hline Group Process & Occa & Never & Occa & Always \\
\hline Resource Management & Occa & Never & Occa & Always \\
\hline Personnel Supervision and Management & Never & Never & Occa & Always \\
\hline Financial and Budget Development & Never & Never & Occa & Always \\
\hline Policy Analysis and Development & Never & Never & Occa & Freq \\
\hline Legend & $\begin{array}{l}\text { Almost Al } \\
\text { Occasiona }\end{array}$ & $\begin{array}{l}\text { ways }=\text { "Alw } \\
\text { lly }=\text { "Occa" }\end{array}$ & $\begin{array}{l}\text { ys"; Freq } \\
\text { Almost I }\end{array}$ & $\begin{array}{l}\text { ently = "Freq"; } \\
\text { cver = "Never" }\end{array}$ \\
\hline
\end{tabular}

Although there were many directions the analysis could take, the focus of this initial analysis centered around three areas that seemed to have the greatest potential for application:

1. Differences between ratings of expertise and need

2. Differences of opinion between administrators and faculty

3. Differences of opinion across disciplinary groups 
Table 7.3. Expertise and Need: International Survey Data

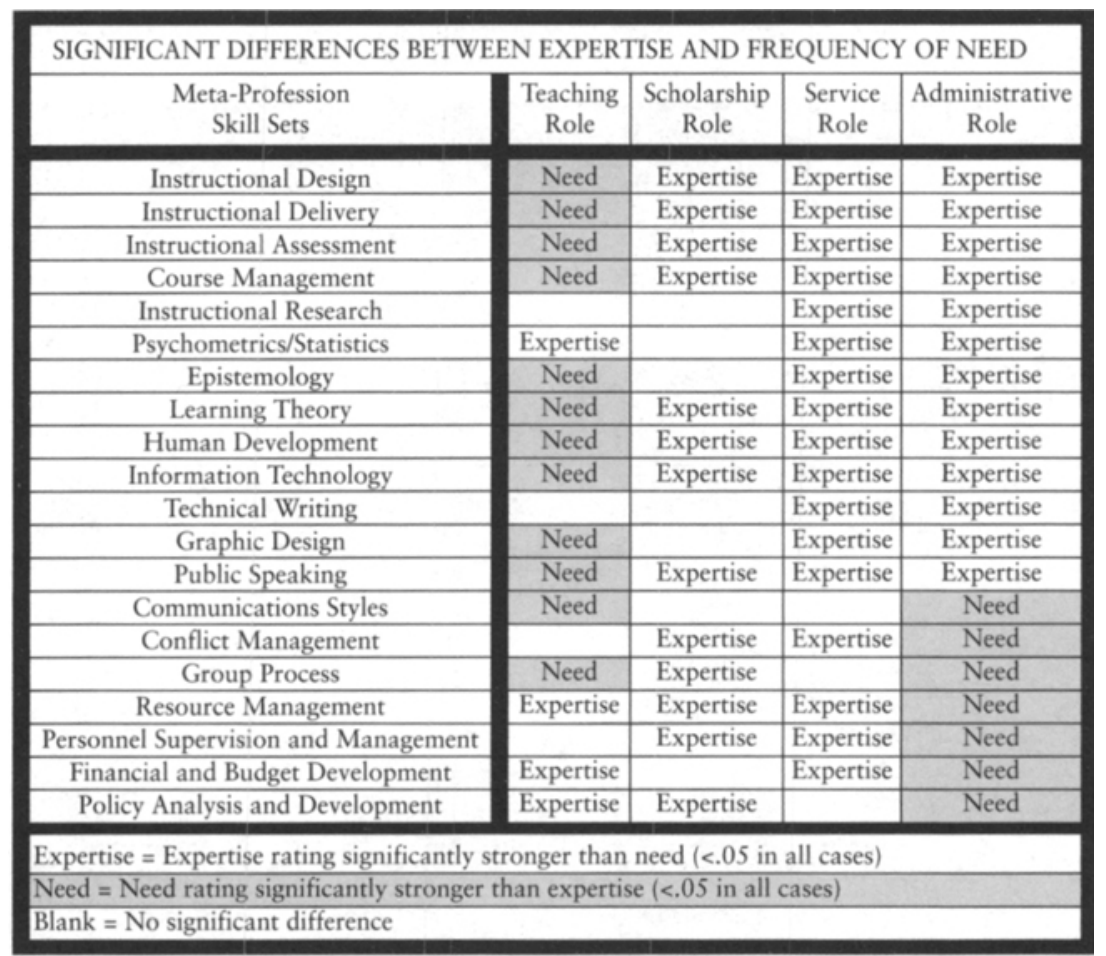

To retain focus on local campus applications, other differences of opinion in the data are omitted. To further facilitate an applied perspective, the data in Tables 7.3 through 7.7 are best viewed with respect to particular faculty evaluation and development issues and strategies for using data to promote dialogue. For example, if one takes the perspective of a faculty development and evaluation committee or the staff of a teaching center, then collection of such campus-specific meta-professional data could be used to initiate open discussion about whether existing policy and practice accurately reflect emphasis on skills that are critical to faculty success. The underlying questions to guide such discussions would include:

- What are "our" expectations for faculty performance?

- What skills are needed to perform well?

- Is the emphasis of evaluation on skills agreed to be critical?

- Are development resources allocated to critical skill areas? 
Further on in this chapter, such an approach will be described to underscore how structured qualitative exploration could be used to clarify differences within an institution and across disciplinary departments. A perspective grounded in local consensus presents the opportunity to actively engage with the data and to make it speak to a specific context, illustrating the core premise of this research: that use of the MetaProfession model to open campus dialogue about faculty roles, work, and skills can lead to a more supportive environment for faculty and to enhanced teaching and learning.

\section{Faculty Expertise: Need Ratings}

Table 7.3 presents aggregated data from the survey. The skill sets are arrayed on the left with the next four data columns showing the rated frequency of need for each skill set in each role. Frequency of need was rated as "almost always" (1.0), "frequently" (2.0), "occasionally" (3.0), and "almost never" (4.0).

The words expertise and need in the cells indicate which rating was significantly stronger. Shading is used to further distinguish need from expertise. Blank cells indicate no significant difference. All significance findings were at alpha levels more stringent than .05 , and most were well below alpha .01 . Similar graphic profiles are displayed in subsequent tables for consistency and readability.

Need and expertise ratings from all respondents were combined and means were compared using $t$ tests. These were used because each respondent furnished a pair of ratings. However, because the two concepts are different, further analyses will be done using correlations or nonparametric tests such as chi square to cross-check the results. The primary question is whether a match between expertise and need exists. If, for example, a skill is "almost always" needed, one would hope that faculty expertise would approach the "advanced" level. If not, then caution is required in the evaluation of that skill, and it would be wise to allocate development resources to enhancing faculty expertise. Expertise ratings ranged from "advanced" through "moderate" and "basic" to "none," with most choices "moderate" or "basic," while the need ratings varied from "almost always" to "almost never." Table 7.3 reveals that the greatest needs are in the teaching and administrative roles in several skill areas. Respondents appear to feel comfortable that skill levels are sufficient to meet needs in the scholarship and service roles. These results are not unexpected because "base profession" training in graduate schools focuses on training in the areas of scholarship but seldom concentrates on 
teaching and administrative skill sets, except in a few disciplines (for example, education, business, psychology). Service appears to be a category where all respondents "almost always" feel fully qualified to carry out their responsibilities.

What these data suggest with respect to faculty development is the importance of using data to drive faculty development activities. Given that resources are often limited (this being an almost universal case in current times), they should target areas of greatest need. When data are collected and analyzed at the institutional level and patterns are found (either similar to or discrepant from the generalized findings), the institution should support professional enrichment activities that focus on the teaching role in certain skill sets and possibly in the administration role for other skill sets. Indeed, separate institutional datasets reveal that this pattern of results is consistent.

The data also make clear that faculty evaluation of certain kinds of skills must be tempered by the realization that a high level of expertise cannot be expected across all faculty, particularly on entry into the profession. Refined expertise cannot be assumed, and comparisons of individuals must thus avoid pitting experienced faculty who may have had the opportunity for training and skill development against those who have not had such opportunities. In other words, evaluation using inappropriate criteria and standards for performance is both poor methodology and unfair practice.

Perhaps more important, if these kinds of data are collected at the institutional level, their first and most important use would be as information to promote open dialogue and discussion about institutional context and realities related to the expectations for faculty work, existing policies and practices in evaluation and development, and identification of areas of need and improvement.

\section{Faculty Versus Administrator Ratings}

The international survey also explored possible differences in the ratings given by faculty ( 54 percent of the respondents) and administrators (46 percent of the respondents). Table 7.4 displays skill sets at the left, overall expertise ratings, and then four sets of needs ratings. As in Table 7.3, the words in the cells indicate which rating was significantly stronger, shading is used to supplement this distinction, and blank cells indicate no signifcant differences. T-tests were used because different groups furnished ratings of the two concepts, and the hypothesis was that there would be no cross-group differences. Each pair of ratings was independent and t-tests 
Table 7.4. Administrator and Faculty Ratings: International Survey Data

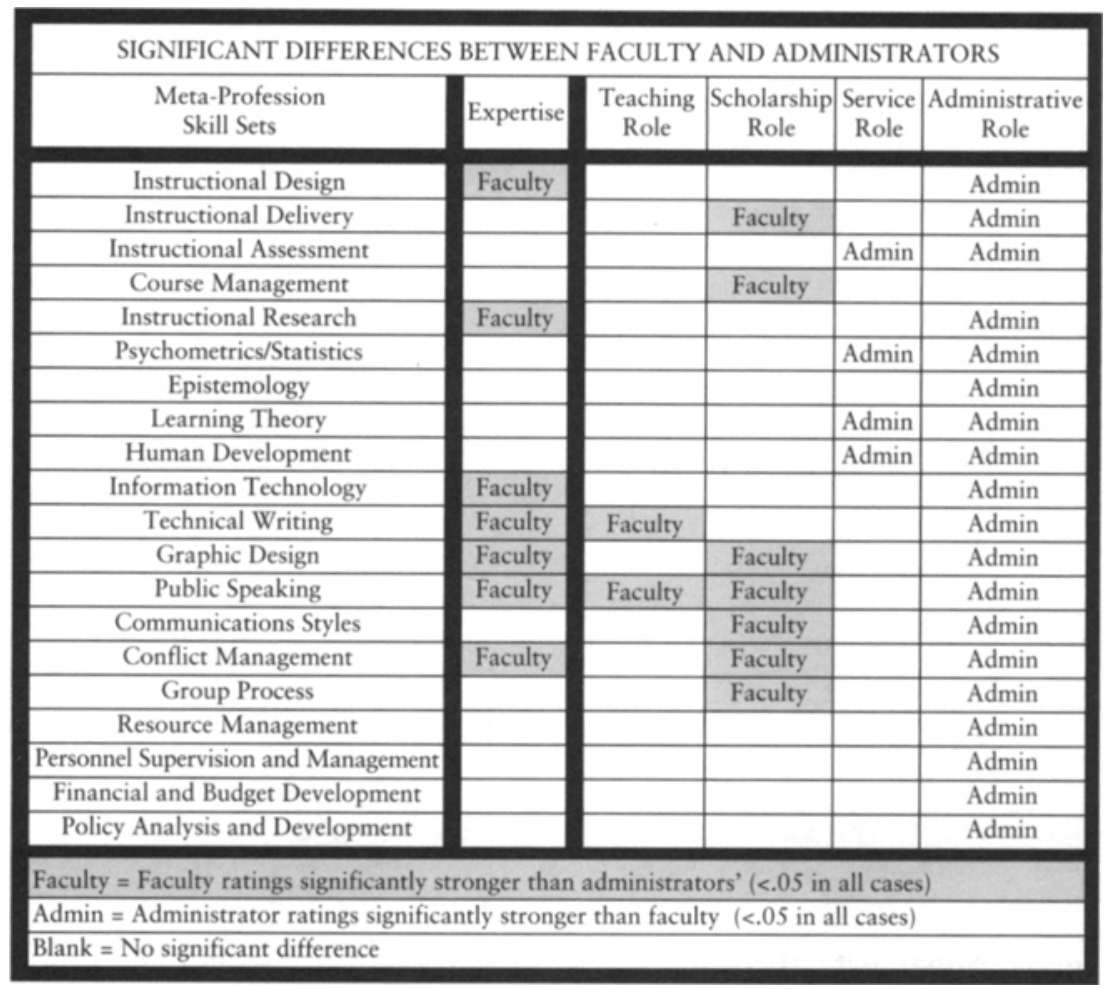

could be used without fear of increasing the chance of type II error. The same rationale applies to Tables 7.5 through 7.7. All significant differences in Table 7.4 were at alpha .05 , and most were well below alpha .01 .

The most striking results are that (1) in no case did administrators rate faculty expertise in any skill sets significantly stronger than did faculty; and (2) in every skill set but one in the administrative role, administrator ratings of need were significantly higher than those of the faculty. The graphic dramatically displays this dichotomous result. A possible explanation for the result is that the demands of the roles are so different that one's perspectives about the importance of skills changes as one moves between roles. If this is the case, when administrators evaluate faculty performance they may assume a higher level of faculty skill than can realistically be expected. However, given that administrators do not rate faculty expertise higher in any instance, this concern may be unwarranted. 
Table 7.5. Disciplinary Differences in Ratings: International Survey Data

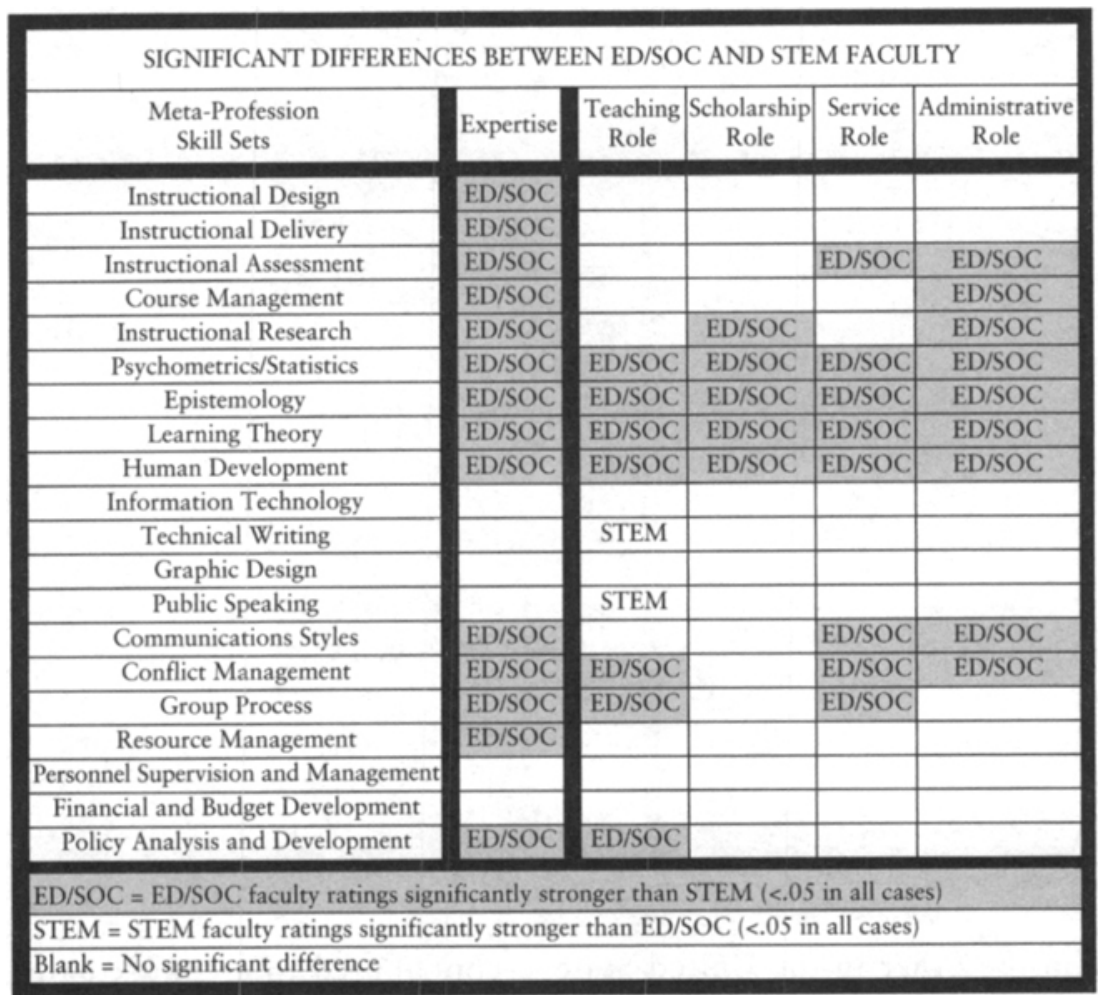

Preliminary review of qualitative data suggests this is true, but this is a tentative explanation at best and further investigation is ongoing.

\section{Disciplinary Differences in Ratings}

The international survey included respondents from more than twentyfour disciplinary areas, but the two largest groups of related disciplines were science, technology, engineering, and math (STEM, 30 percent of the sample) and education and social science (ED/SOC 40 percent). These two groups were chosen for additional analysis. Table 7.5 uses the same graphic patterns as previous tables. Significant differences are indicated by the presence of words in the cells and by shading, and blank cells indicate no significant differences. Alpha levels are all at .05 or lower, and most differences are at alpha levels below .01. T-tests were used in this analysis because two groups were rating the same concepts. 
One result is somewhat predictable: ED/SOC faculty would rate their expertise in teaching-related skill sets higher than would STEM faculty. However, the noticeable differences extend beyond those skill sets into many other skill sets and almost thirty of the frequency-of-need ratings. STEM ratings were significantly stronger than ED/SOC ratings in only two cases (need for technical writing, and public speaking in the teaching role). Apparently, disciplines have very different perspectives, values, and criteria for performance, as found in other studies (for example, Biglan, 1973; Franklin \& Theall, 1992; Smart, Feldman, \& Ethington, 2000). Two important implications for evaluation arise: (1) that the values and performance criteria of one discipline should not be used to judge performance of a person in another discipline, and (2) that exploration of disciplinary differences should be part of good evaluation practice on every campus.

\section{Institutional Data and Contextually Grounded Perspectives}

As suggested here, the most effective application of the Meta-Profession model will take place at the institutional level. It is there that the concept and associated tools can be used to increase understanding of unique institutional identity and dynamics that define the professoriate. This understanding can directly result in improvements in policy and practice in faculty development and evaluation as well as related improvements in teaching and learning, organizational effectiveness, and institutional performance.

To support application of the model, two institutions-one in Canada and the other in the United States-contributed to a contextually grounded dataset by prioritizing participation in the survey. The focus of the next section is on the U.S. institution, the survey findings, and their relationship to the international dataset.

\section{A Local Institutional Study: Expertise and Needs Ratings}

A local data collection effort essentially identical to the international survey was conducted concurrently with the international survey. Seventyfour responses were received (approximately 25 percent of full-time faculty) and analyzed in the same way as those in the large survey. The first analysis compared expertise and need ratings. Table 7.6 presents the local data in the same manner as did Table 7.2. T-tests were used as before with alpha levels at .05 or less and most below .01 . These results present a close match with the international data with respect to frequency of need for the skill sets across the four roles. The number of significantly stronger expertise ratings differs by only one. The number of 
Table 7.6. Expertise and Frequency of Need Ratings: Institutional Data

\begin{tabular}{|c|c|c|c|c|}
\hline \multicolumn{5}{|c|}{$\begin{array}{l}\text { SIGNIFICANT DIFFERENCES BETWEEN INSTITUTIONAL } \\
\text { EXPERTISE AND NEED RATINGS }\end{array}$} \\
\hline $\begin{array}{l}\text { Meta-Profession } \\
\text { Skill Sets }\end{array}$ & $\begin{array}{c}\text { Teaching } \\
\text { Role }\end{array}$ & $\begin{array}{c}\text { Scholarship } \\
\text { Role }\end{array}$ & $\begin{array}{l}\text { Service } \\
\text { Role }\end{array}$ & $\begin{array}{c}\text { Administrative } \\
\text { Role }\end{array}$ \\
\hline Instructional Design & Need & Expertise & Expertise & Expertise \\
\hline Instructional Delivery & Need & Expertise & Expertise & Expertise \\
\hline Instructional Assessment & Need & Expertise & Expertise & Expertise \\
\hline Course Management & Need & Expertise & Expertise & Expertise \\
\hline Instructional Research & & & Expertise & Expertise \\
\hline Psychometrics/Statistics & Expertise & & Expertise & Expertise \\
\hline Epistemology & & & Expertise & Expertise \\
\hline Learning Theory & & Expertise & Expertise & Expertise \\
\hline Human Development & & Expertise & Expertise & Expertise \\
\hline Information Technology & & Need & Expertise & \\
\hline Technical Writing & & & Expertise & Expertise \\
\hline Graphic Design & & Expertise & Expertise & Expertise \\
\hline Public Speaking & Need & Expertise & Expertise & \\
\hline \multicolumn{5}{|l|}{ Communications Styles } \\
\hline Conflict Management & & Expertise & Expertise & \\
\hline Group Process & Need & Expertise & & \\
\hline Resource Management & Expertise & Expertise & Expertise & Need \\
\hline Personnel Supervision and Management & & Expertise & & Need \\
\hline Financial and Budget Development & Expertise & Expertise & Expertise & Need \\
\hline Policy Analysis and Development & Expertise & Expertise & Expertise & Need \\
\hline \multicolumn{5}{|c|}{ Expertise $=$ Expertise ratings significantly stronger than need $(<.05$ in all cases $)$} \\
\hline lank = No significant difference & & & & \\
\hline
\end{tabular}

cells showing significantly stronger needs ratings is only slightly fewer. This reflects some differences in the expertise mean scores (not displayed here). The expertise ratings are stronger in the local data, yielding fewer differences with need ratings in the teaching and administration roles. The mean scores for local versus international were not analyzed for significant differences, but in some cases (for example, psychometrics/statistics and resource management) the numeric differences were large (almost a full point weaker in the international sample).

This might be expected, however, because a previous analysis (Theall et al., 2008) found significant differences across four institutional types based on Carnegie classification. The international sample would have homogenized the results from all types of institutions, and thus a mean expertise score at any one institution might differ considerably from the overall sample score in any skill set and role combination. Further, the respondent pool changes within this context, and the potential for increased 
Table 7.7. Disciplinary Differences in ED/SOC and STEM: Institutional Data

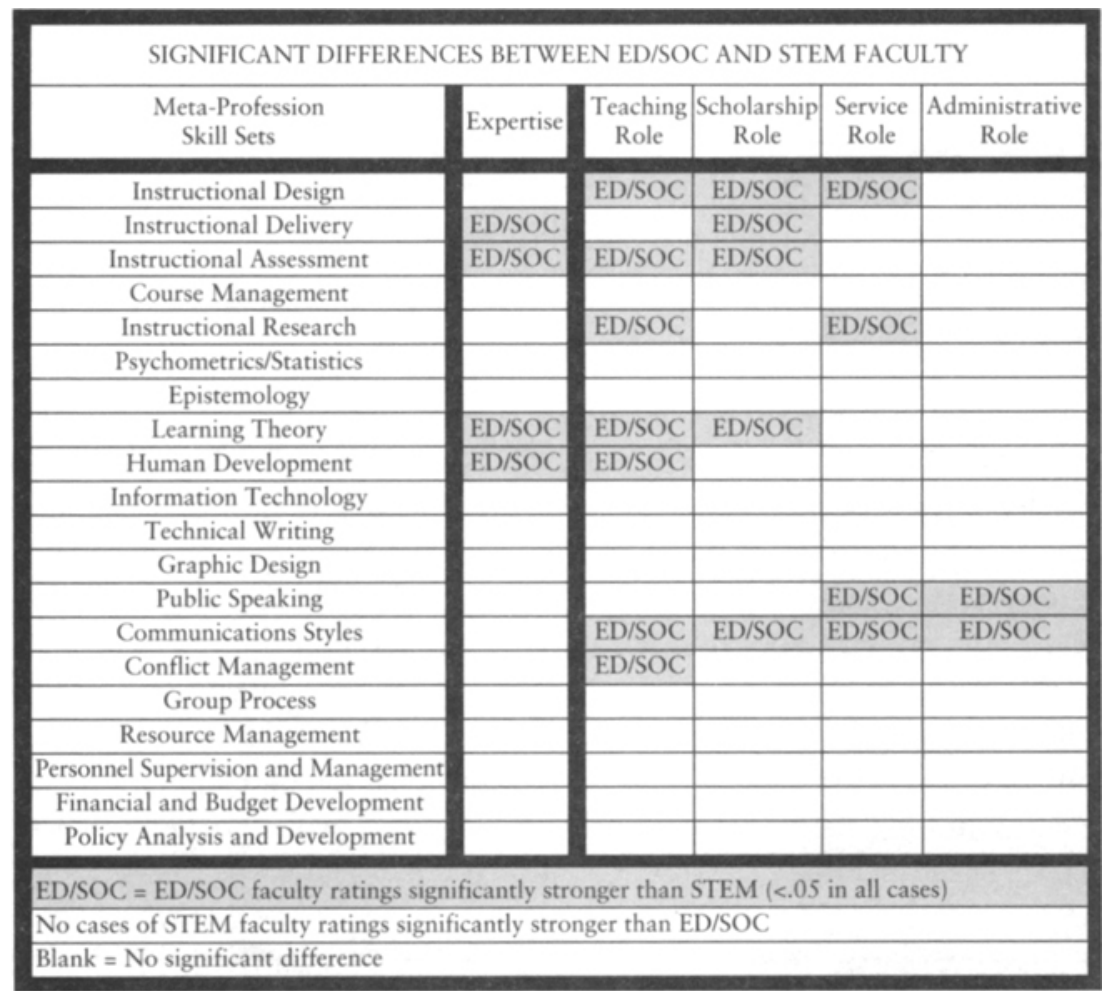

percentages of faculty respondents as compared to administrator/faculty developer responses may also shift the findings. In all cases, the local data become critical and comparison with the international profiles is useful primarily to prompt reflection and dialogue.

\section{A Local Institutional Study: Disciplinary Difference Ratings}

Data from the local institution were analyzed for disciplinary differences using the same disciplinary groups as in the international survey. Fortunately, the local sample contained the same disciplinary diversity as the international sample. Of the seventy-four respondents, ten were from STEM disciplines and thirteen from ED/SOC disciplines. Data from the analysis are presented in Table 7.7 in the same manner as before. Analysis was similar, and significant results were at the same alpha levels. 
As in the expertise-need analysis, results from the local institution were very similar to those in the international survey, though not as pronounced in terms in the number of significant differences. ED/SOC expertise and need ratings were significantly stronger in some cases and in similar cells. The more coherent nature of the local sample and regression toward the mean in the larger sample may account for this. STEM ratings were not significantly stronger in any case. As before, established disciplinary differences may account for the results, but more investigation is necessary before reaching firm conclusions.

\section{A Qualitative Extension of the Research}

Ultimately, the interest in this study is fueled by its capacity to serve as a lever for change: to be a mechanism for reflection and dialogue that can help to unveil the professoriate and reveal context-specific issues that have an impact on faculty success. This implies a process of qualitative, participatory research that begins by referencing relevant data, such as that collected and presented above. Further, although the results of the local study were very interesting in their own right and informative when considered in relation to the international results, the local data analysis raised several questions not directly answerable through examination of quantitative data. Review of the local results coupled with prior review of the literature (for example, Birnbaum, 1988, on institutional types; Hativa \& Marincovich, 1995) suggested that there would be unique characteristics but that the quantitative survey methodology was insufficient to unearth the reasons for the differences. To dig more deeply, a qualitative follow-up study and process was initiated. Its intention: to use the quantitative survey findings as a prompt for active exploration of a contextually grounded interpretation of the Meta-Profession model given local institutional realities.

This portion of the study is ongoing, and the discussion here represents preliminary results emerging from two initial interviews and one focus group. Thus far, respondents include three administrators from ED/SOC disciplines and one faculty member in education. Participants spent roughly one hour with the interviewer, were introduced to the local and international results, and were asked to reflect on them and consider how these points related to open-ended questions that served as discussion prompts: What are the most important skills faculty members in your department need to succeed? How do they acquire these skills? How are the skills evaluated?

Methodologically, this took an action research approach and was designed to engage key stakeholders in collaboratively exploring 
information that may expand their understanding and suggest action at the individual, departmental, or institutional level. Established qualitative research protocols were employed with grounded theory informing the initial coding and analysis of these interviews, as author-researchers identified emergent themes to allow their growth and ongoing validation (Strauss \& Corbin, 1998). Periodic informal and formal discussions among author-researchers served as an inductive base to identify themes of topic impact that were further enhanced and explored using NVivo Qualitative Software (QSR International, 2007). Recoding strategies were used to increase validity by generating initial free nodes (stand-alone indicators) and subsequently exploring relationships by establishing treenoded categories (related categories of indicators), supporting each with quotations and emergent analysis (Richards, 1999). Though preliminary and limited in scope, as anticipated, the results begin to echo, reinforce, and reveal differences reflected in the quantitative data while revealing some important distinctions.

\section{A Summary of Emergent Themes}

Small focus group conversations with three department chairs from education and social science and an individual interview with a faculty member in education revealed a consistency in categories of opinions expressed. For the sake of brevity, we present these emergent themes in Table 7.8.

The tone, focus, and content of faculty and administrator responses continued to differ within these interview contexts sufficiently to justify their separation (making them easier to consider with respect to the quantitative survey results, such as those in Table 7.4). We also found that the contributions seemed to fall into three primary categories of consideration: faculty skills, faculty development, and departmental needs. These reflected both the initial prompt questions and the specifics of the context. Although the summary terms used here are drawn from the phrases offered by interviewees, the majority of the faculty skills cited are directly reflected in the Meta-Professional skill set, either directly (for example, communication) or indirectly with a term that encompassed several skill sets (diplomatic and people skills, drawing from conflict management, communication, group process and team building, personnel management, and so on). There were also emergent themes that were not readily reflective of existing skills sets that have context-specific and disciplinary relevance and will be mentioned later. First, here are some revealing and illustrative quotes that help to clarify the motivations and perspectives of respondents vis-à-vis the themes we have noted. 


\section{Table 7.8. Emergent Themes from Qualitative Study}

\begin{tabular}{|c|c|c|c|}
\hline & Faculty Skills & $\begin{array}{c}\text { Faculty } \\
\text { Development }\end{array}$ & Department Needs \\
\hline $\begin{array}{l}\text { Administrator } \\
\text { responses }\end{array}$ & $\begin{array}{l}\text { Communication } \\
\text { skills } \\
\text { Knowledge of local } \\
\text { area and people* } \\
\text { Diplomatic skills } \\
\text { (dealing with people) } \\
\text { Teaching and schol- } \\
\text { arship (traditional) } \\
\text { Specific teaching } \\
\text { experience in a } \\
\text { program area } \\
\text { Teaching skills (for } \\
\text { cross-appointed } \\
\text { faculty)* }\end{array}$ & $\begin{array}{l}\text { Mentoring (chair } \\
\text { or others) } \\
\text { Formative feed- } \\
\text { back (years } \\
1-3 \text { ) } \\
\text { Collaboration } \\
\text { with peers } \\
\text { Institutional } \\
\text { programs } \\
\text { Professional } \\
\text { programs }\end{array}$ & $\begin{array}{l}\text { Areas of specializa- } \\
\text { tion of candidates } \\
\text { Balance of skills } \\
\text { across department } \\
\text { Mix of skills and } \\
\text { experience } \\
\text { Collaborative } \\
\text { potential } \\
\text { "Team members" } \\
\text { Public relations and } \\
\text { external influence } \\
\text { (collegiality?) }\end{array}$ \\
\hline $\begin{array}{l}\text { Faculty } \\
\text { responses }\end{array}$ & $\begin{array}{l}\text { Teaching skills most } \\
\text { important } \\
\text { Scholarship skills } \\
\text { related to the } \\
\text { discipline } \\
\text { Service distracting } \\
\text { Personal challenges } \\
\text { and finding balance }\end{array}$ & $\begin{array}{l}\text { Mentoring } \\
\text { Laissez faire, } \\
\text { "trial and } \\
\text { error" }\end{array}$ & $\begin{array}{l}\text { Administrator } \\
\text { expectations- } \\
\text { need for clarity, } \\
\text { implications for } \\
\text { success, fairness } \\
\text { and consequences } \\
\text { Public relations and } \\
\text { external advocacy } \\
\text { and influence }\end{array}$ \\
\hline
\end{tabular}

Note: $=$ Pertains to ED/SOC but not necessarily to all disciplines.

Administrators shared these, regarding:

- What they look for when hiring new faculty:

- Teaching and scholarship, mix of skills and experience: "As a chair, I look for success in teaching, but the university looks for publications."

- Communication, public relations, collegiality: "I look for someone who has diplomatic skills and good personal relations skills."

- Balance of skills: "I try to assemble a group of people who meet all the needs of the department."

- How they support faculty professional development:

- Mentoring and formative feedback: "In the new faculty member's first three years, my role is as a mentor and someone 
who can provide formative feedback about performance and growth, so that in the ensuing years, the person has the best chance to prepare for and to succeed in the promotion and tenure process."

The first faculty member mentioned:

- Faculty needs, skill areas:

- On teaching: "If I had to categorize what's most important to me, I would like to suggest being an effective teacher."

- On scholarship: "I would also say that scholarship is critical. I am constantly expanding my awareness and my sense of what is important in education. Both from the standpoint of theory and practice and where we live, in terms of what is impacting the educational sector."

- On service: "Service is important, but I will be honest with you, sometimes it deters, it mitigates against my ability to really dive into the scholarship, and hence to make the greatest impact that I would like to in the teaching."

- Personal challenges and finding balance: A difficult issue is "making the transition between negotiating the roles of single parent and the commitments that are nonnegotiable with the expectations and the mandates ... for promotion and/or other benefits that go with the role of one who is on a tenure track.... There is a tension there. ... And how I successfully engage those two has been very difficult."

- Faculty development:

- On support to faculty: "Now should there be a commitment to ensure that the faculty have the best opportunity to develop the expected skills? In all fairness, yes, especially if the evaluation process suggests that my moving forward has been beneficial to me."

- Intermittent lack of support: "A lot has been left to trial and error except for maybe the conversations that occur between myself and mentors. ... I feel, maybe more is going to be unveiled ... a I I continue on here. But I think there's this silent understanding that it's supposed to "just happen."

- A suggestion: "[It] would be meaningful to have a formal opportunity even if it's just two ... or one a semester, to actually have a meeting ... in terms of what the administration expects: what you know in general, down to the specifics of 'Here it is, and 
these are some possibilities to explore to how to get to [the] goals."

- Administrator stance and opinions (department needs):

- Public relations and external advocacy, influence: "They [administrators] want to present the best picture that their faculty members are on top."

- Departmental expectations: "I got a pretty good sense ... from your survey, that they [administrators] are expecting more than I thought or at least there is ... a sense that you should know something about these pieces [the skills].... I think ... it challenges me to balance it [the skills-roles demands] and so I'm mindful . . . because if I don't, it could result in negative action ... although the beginning instructor may not have a handle of the skills beyond the basic level, the expectation that ... as you matriculate somehow you will be endowed.... I feel that I've still been held accountable. ... Is that fair? I don't know."

There are several emergent themes embedded in both Table 7.8 and the quotes offered by interviewees. They move beyond the task-focused Meta-Profession skills and present us with both suggestions and insights into context-influenced issues. Three of these themes that surface from faculty and administrator conversations are collegiality, balance, and community connections and networks. Collegiality is the elusive term that benefits from open discussion and collaborative definition. Additional interviews will undoubtedly help to flesh this term out for the study and for institutional participants. Balance emerges in multiple forms: from the classic balance challenge associated with teaching, scholarship, and service to administrators projecting the need to broadly consider their faculty's skills and expertise to create a balanced departmental profile, to faculty referencing the challenge of balancing professional and personal lives.

\section{Limitations and Future Research}

Beginning with the survey, it is relevant to note that even though the current international sample is sufficiently large to allow some analysis, many issues require further exploration. For example, accurate description of disciplinary differences would require a substantially greater number of responses from each disciplinary area. A gender breakdown in the current sample ( 66 percent female, 33 percent male) would allow 
some analysis, but the numbers are too small to explore whether gender differences (if they exist) hold across disciplines, academic ranks, years of experience, type of appointment, or location in different Carnegie institutional types. Thus, one practical and logistical problem is that the current sample is limited in terms of its representativeness, and this fact would likewise limit the analysis that can be done. Should resources become available that would support a coordinated effort to gather a truly large sample of faculty and administrator responses, this would allow such enhanced analysis and mark a next step toward understanding the effects of many variables on opinions about faculty roles, skills, and needs. In addition, expanded analyses of expertise and needs ratings should be considered (for example, chi-square analysis may prove more suitable than significance testing for mean score differences in comparisons of expertise and need).

A second limitation relates to the intended use of the survey and other mechanisms to collect unique institutional data. Again, even if overall results from analyses of gender, rank, and so on were available, local samples may be too small to examine whether or not they agree with the general results. Qualitative research approaches may well help to resolve questions, but such collaborative data collection, analysis and interpretation, though potentially transformative, is generally a time- and costintensive process.

\section{Tentative Conclusions and Recommendations}

The potential of this model, survey, and process for promoting community conversations around faculty roles, responsibility, development, and evaluation continues to hold promise. Whereas limitations exist, the ability to overlay an integrated research approach and action research methodology allows us to propose a process that consolidates efforts and moves more quickly from findings to action. We have developed and pretested a promising process whereby quantitative data is coded into visible patterns in profiles and used to prompt discussions that reveal qualitative insights regarding contextualized meaning while simultaneously promoting action.

Recognizing that institutional patterns differ, effective use of a metaprofessional approach requires local data collection and analysis with particular attention to context-sensitive variables that could affect results. To date, preliminary analysis suggests such factors include the Carnegie classification of the institution and its size, location, mission, and resources. Disciplinary focus appears to be a variable of influence, 
and further examination of the current sample may suggest that other variables can affect opinions, perceptions, and understanding as well.

In general, the current results present sufficient and consistent patterns of responses that suggest a number of conclusions and recommendations.

\section{For Findings}

- Faculty expertise and need across roles. In skills related to teaching and administration, faculty expertise may be less than desired. The strongest areas of need for meta-professional skills are in teaching and administration. The teaching role is designated as having greater frequency of need and thus is a more likely first target for faculty development intervention and support. In remaining areas, expertise in the meta-professional skill sets is generally considered to be sufficient both for service activities (where the weakest felt need for the skills exists) and for scholarly and creative activities (where base profession preparation is strongest). Institutional determinations may differ.

- Differing perspectives by roles. Administrators and faculty differ considerably in their ratings of faculty expertise and in their perceptions about the need for almost every skill in the administrative role. The perceptions of administrators are both colored and broadened by the demands of their positions, and thus they ascribe more importance to almost all skill sets with respect to the administrative role. The perceptions of department-chair-level administrators are influenced by their views on the needs of their departments; they look for a balance of skills across their faculty rather than a full set of skills in every member of the faculty.

- Differing perspectives by affliation and status. Opinions differ about both expertise and need for skills across at least some disciplines. The perceptions of pretenure faculty center on meeting the perceived needs and expectations of the department and the administration, and these expectations cut across all roles and skill sets.

\section{Recommendations for Process}

- The Meta-Profession model can be used as a vehicle for exploration of institutional issues as they relate to the professoriate and as a mechanism to prompt targeted improvement.

- An integrated approach, strategically using quantitative and qualitative data collection, can give a more complete picture of 
institutional perspectives on faculty skills and roles than either process alone.

- Data collection must be followed by ongoing dialogue about both the results and the topics. In other words, collecting data purely as a research effort will not promote improved policy and practice or institutional and organizational development.

- Community dialogue is well informed by data and results in additional qualitative insights.

- Engagement and deliberation are required for actionable outcomes to emerge.

- Dialogue on organizational improvement must be a continuous process.

As evident from the approach put forth, the strength of this research and the model will come from its expansion and contextually grounded application by scholar-practitioners in the field. The opportunity to share this research model with POD colleagues under the banner of the Menges Honored Presentation Award at the POD 2008 Conference further affirmed the findings and expanded the conception of ways it could be used. It prompted suggestions ranging from various ways to envision the model graphically to assorted applications such as guided mentoring, clarification of tenure and promotion expectations, frameworks for evaluation, and more. The Meta-Profession Project is open to continued investigation and to more interested, thoughtful, and reflective colleagues joining the journey to explore and support the professoriate and the advancement of teaching and learning in the academy.

\section{REFERENCES}

Arreola, R. A., Theall, M., \& Aleamoni, L. M. (2003, April). Beyond scholarship: Recognizing the multiple roles of the professoriate. Paper presented at the 83rd annual meeting of the American Educational Research Association, Chicago.

Biglan, A. (1973). The characteristics of subject matter in different academic areas. Journal of Applied Psychology, 73(3), 195-203.

Birnbaum, R. (1988). How colleges work: The cybernetics of academic organization and leadership. San Francisco: Jossey-Bass.

Boyer, E. L. (1990). Scholarship reconsidered: Priorities of the professoriate. San Francisco: Jossey-Bass.

Braskamp, L. A., \& Ory, J. C. (1994). Assessing faculty work: Enhancing individual and institutional performance. San Francisco: Jossey-Bass. 
Diamond, R. M., \& Adam, B. E. (1995). The disciplines speak: Rewarding the scholarly, professional, and creative work of faculty. Washington, DC: American Association for Higher Education.

Diamond, R. M., \& Adam, B. E. (2000). The disciplines speak II: More statements on rewarding the scholarly, professional, and creative work of faculty. Washington, DC: American Association for Higher Education.

Franklin, J. L., \& Theall, M. (1992, April). Disciplinary differences, instructional goals and activities, measures of student performance, and student ratings of instruction. Paper presented at the 73rd annual meeting of the American Educational Research Association, San Francisco.

Gappa, J. M., Austin, A. E., \& Trice, A. G. (2007). Rethinking faculty work: Higher education's strategic imperative. San Francisco: Jossey-Bass.

Hativa, N., \& Marincovich, M. (Eds.). (1995). New directions for teaching and learning: No. 64. Disciplinary differences in teaching and learning: Implications for practice. San Francisco: Jossey-Bass.

QSR International. (2007). NVivo 8 fundamentals and Moving on with NVivo 8. Cambridge, MA: Author.

Richards, L. (1999). Using NVivo in qualitative research. London: Sage.

Smart, J. C., Feldman, K. A., \& Ethington, C. A. (2000). Academic disciplines: Holland's theory and the study of college students and faculty. Nashville, TN: Vanderbilt University Press.

Strauss, A., \& Corbin, J. (1998). Basics of qualitative research: Grounded theory, procedures, and techniques. Thousand Oaks, CA: Sage.

Theall, M. (2002, April). Leadership in faculty evaluation and development: Some thoughts on why and how the meta-profession can control its own destiny. Invited address at the 82nd annual meeting of the American Educational Research Association, New Orleans, LA.

Theall, M., \& Arreola, R. A. (2006). The meta-profession of teaching. NEA Higher Education Advocate, 22(5), 5-8.

Theall, M., Arreola, R. A., Mullinix, B., Franklin, J., Svinicki, M., \& Chism, N.V.N. (2008, March). The roles and skills of faculty in US and UK higher education institutions: What faculty need to succeed. Paper presented at the 87th annual meeting of the American Educational Research Association, New York. 